\title{
Studies on soil Anions, Cations and Enzyme Activities of Waste Petroleum Product Dumpsites at Mgbunjuku Port - Harcourt Nigeria
}

\author{
Chinyere, G.C. , Nwankwo, T.N and Osuocha, K.U. \\ Department of Biochemistry Abia State University Uturu, Nigeria.
}

\begin{abstract}
The physicochemical analysis, inorganic ion concentrations, some selected enzyme activities and metal concentrations of polluted soils in locations within Mgbunjuku Diobu Port Harcourt, Nigeria were determined. The soil temperature $\left({ }^{\circ} c\right)$ ranged from (26.60-27.20) while the $\mathrm{pH}$ values ranged from (5.8-6.8). The cation exchange capacities and exchangeable acidities have ranges of $4.0-10.40 \mathrm{Mkg}^{-1}$ and $0.10-0.74 \mathrm{Mkg}^{-1}$ respectively which showed significant difference (0.05) from the controls. The soil anions, ( nitrate, sulphate, chloride) showed significantly higher values of $5.60 \%-28.20 \%, 14.09 \%-5.85 \%$ and $2.49-1.07 \%$ respectively when compared to their control values. The soil phosphate showed significantly $(p \leq 0.05)$ lower values of 45.08 $57.87 \%$ compared to controls (53.94-61.80\%). Similarly soil enzymes activities of dehydrogenase, alkaline and acid phosphatases were significantly lower than the control values while lipase activity was significantly higher $(p \leq 0.05)$ than the control. Soil metal concentrations were also significantly higher $(p \leq 0.05)$ in polluted than the unpolluted soils (controls) except for Ca and Mg. This study therefore showed that the dumping of waste petroleum products affects the soil nutrients, destroys the soil ecosystem and may have

adverse effects on plant growth.
\end{abstract}

Key Words: Waste petroleum, dumpsites, anions, cations, enzyme activities

\section{Introduction}

Petroleum or crude oil is a naturally occurring flammable liquid consisting of a complex mixture of hydrocarbons of various molecular weights and other liquid organic compounds that are found in geological formations beneath the surface of the Earth [1]. A fossil fuel is formed when large quantities of dead organisms usually zooplankton and algae are buried underneath sedimentary rock and undergo intense heat and pressure. It is recovered mostly through drilling and refined into large number of consumer products from petrol (or gasoline) and kerosene to asphalt and chemical reagents used in manufacturing plastics, pharmaceuticals and other wide variety of material.[1].

The use of fossil fuel such as petroleum can have negative effect on Earth's biosphere releasing pollutants and green house gases into the air and damaging ecosystems through events such as oil spills and used petroleum products dumping on soils. The massive and extensive pollution of these environments constitute socio-economic and public health hazards. Kobayashi and Rithman,[2] reported that these foreign compounds that are indiscriminately discharged into the soil cause serious toxicity problems to the microorganisms and thus change the soil nutrients for plant growth. Waste oil (used oil containing breakdown products and impurities from use) which includes hydraulic oil, transmission oil, brake fluids, motor oil, gear box oil and synthetic oil from vehicles drips off engines over streets and roads; the oil travels into the water table bringing with it such toxins as benzene.

These poison both soil and drinking water. Benzene, which is a component of cruds oil, is known to have serious toxic effect on bone marrow and chronic exposure to benzene may cause leukemia [3].

Most such problems associated with natural petroleum, exist with used petroleum products (waste oil). Waste oil exert adverse effects on plants indirectly by reducing the soil nutrients and making available toxic minerals to the soil[4].

Waste oil dumping on soil leads to decrease in fertility of the soil as a result of decrease - in enzyme activities especially dehydrogenase and arylsulphatase, decrease in inorganic anionic levels in soil especially nitrate, sulphate and chloride with an increase in the level of inorganic cation [4].

The objective of this study is to determine the inorganic ion level of the polluted soils, activities of selected soil enzymes and thus relate them to effects on soil physicochemical properties, fertility and usage.

\section{Materials And Methods}

Study Area

Mgbunjuku is a community settlement which is located in Diobu and also known as Ikokwu in Mile 2 Diobu Port - Harcourt Rivers state Nigeria. The inhabitants of this place are mostly artisans who repair vehicles and earth moving equipments. 


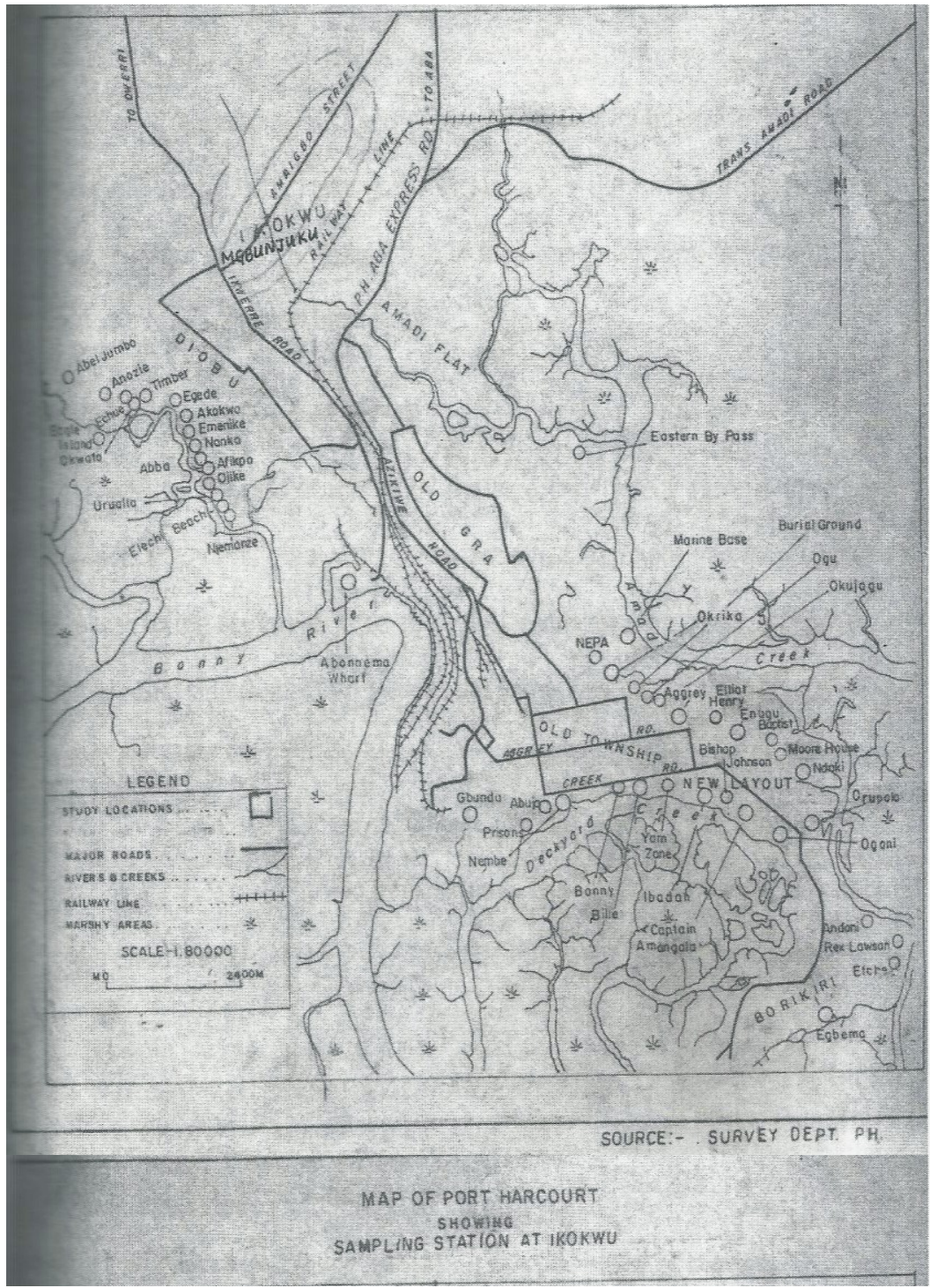

\section{Soil Sample Collection}

The study area was divided into transects of Central, North, South, East and West. An unpolluted area adjacent to the South was used as control. Samples were collected from the Central, $10 \mathrm{~m}$ and 20m Northwards. The same was done Southwards, Eastwards and Westwards respectively using plastic auger. Samples were collected from depths of $0-25 \mathrm{~cm}$ and $26-50 \mathrm{~cm}$ from each spot. The temperature and $\mathrm{pH}$ of the soil samples were determined on site after which samples were transported in plastic bags containing ice packs to the soil Biochemistry laboratory of Abia State University, Uturu for further analysis.

\section{Soil Sample Preparation and Storage}

Soil sample for enzyme activities determination were stored in the refrigerator $\left(5-8^{\circ} \mathrm{c}\right)$ for preservation before use. Analysis of these soil samples were done within one week of sample collection. Sub-soil samples were air-dried, ground (gentle crushing between sheets of polythene) and sieved through a $2 \mathrm{~mm}$ mesh as adopted as an international standard since the soil passing through this mesh contains almost the whole of the nutritional important fraction of the soil [5]. Nylon sieve was used in preference to metal sieve to eliminate possible contaminations of the soil samples.

A total of twenty soil samples were used for the analysis of inorganic anions and selected soil enzymes. The soil samples so prepared were stored in stoppered plastic bottles until analysis. All reagents used in this study were of analytical grade obtained from Sigma Chemical Company st. Louis Missourri.

\section{Physico-chemical Analysis}

The soil temperature was determined in situ at the site of sample collection using mercury in glass thermometer while the soil $\mathrm{pH}$ was determined ex-situ using the glass electrode $\mathrm{pH}$ meter ( $1.25 \mathrm{soil} /$ water ratio) 
(Bates, [6]. The soils exchangeable acidities and cation exchange capacities were obtained through methods described by Dewis and Freitas [7].Similarly soil anions: phosphate, nitrate, sulphate and chloride ions were measured as described by Dewis and Freitas[7]. The use of Atomic Absorption Spectrophotometry (AAS) was employed for the determination of exchangeable cations of the soil extract after mixed acid digestions were carried out on the soil sample. The spectrophotometer (spectrum lab 722S, England) was standardized using the standard solution of the element being analyzed and acidified distilled water were aspirated to zero the instrument. Sample extracts were aspirated and concentrations read off the instrument. The soil sample dehydrogenase enzyme was measured using the method described by Thalman [8]. This involves estimation of the triphenyl tetrazolium chloride (TTC) reduction rate to triphenyl formazan (TPF) after which the optical density of the supernatants were measured against the blank at 548nm.

The soils acid and alkaline phosphatases were determined by the colorimetric end point method (Diagnostic Kit by TECO) while the soil lipase enzyme was obtained as described by Allen et al., [5]. The statistical analysis were obtained using analysis of variance (ANOVA) and comparism with controls done using the Duncans multiple range Test $(\mathrm{P} \leq 0.05$, significant level).

\section{Results and Discussions.}

TABLE 1: SOIL SAMPLES PHYSICOCHEMICAL PARAMETERS

\begin{tabular}{|c|c|c|c|c|c|c|c|c|}
\hline \multirow{2}{*}{$\begin{array}{c}\text { Parameter } \\
\text { Soil Depth }\end{array}$} & \multicolumn{2}{|c|}{ Temperature $\left({ }^{\circ} \mathrm{C}\right)$} & \multicolumn{2}{|c|}{ pH } & \multicolumn{2}{|c|}{ Cation exchange capacity $\left(\mathrm{cM} \mathrm{kg}^{-1}\right)$} & \multicolumn{2}{|c|}{ Exchange acidity $\left(\mathrm{cMkg}^{-1}\right)$} \\
\hline & $\mathrm{A}$ & $\mathrm{B}$ & $\mathrm{A}$ & $\mathrm{B}$ & $\mathrm{A}$ & $\mathrm{B}$ & A & $\mathrm{B}$ \\
\hline \multicolumn{9}{|l|}{$\begin{array}{l}\text { Location of } \\
\text { sample } \\
\text { collection }\end{array}$} \\
\hline $\mathrm{N}_{1}$ & $26.80 \pm 0.01^{\mathrm{b}}$ & $27.20 \pm 0.03^{\mathrm{a}}$ & $5.80 \pm 0.01^{b}$ & $6.20 \pm 0.02^{\mathrm{e}}$ & $9.20 \pm 0.04^{b}$ & $4.40 \pm 0.05^{\mathrm{g}}$ & $0.61 \pm 0.03^{\mathrm{b}}$ & $1.10 \pm 0.05^{\mathrm{f}}$ \\
\hline $\mathrm{N}_{2}$ & $26.70 \pm 0.03^{\mathrm{b}}$ & $27.00 \pm 0.02^{\mathrm{a}}$ & $5.90 \pm 0.02^{\mathrm{c}}$ & $6.10 \pm 0.03^{\mathrm{f}}$ & $9.60 \pm 0.05^{\mathrm{c}}$ & $4.40 \pm 0.06^{\mathrm{g}}$ & $0.61 \pm 0.05^{\mathrm{b}}$ & $1.22 \pm 0.01^{\mathrm{g}}$ \\
\hline $\mathrm{E}_{2}$ & $26.90 \pm 0.03^{\mathrm{a}}$ & $27.20 \pm 0.02^{\mathrm{a}}$ & $6.10 \pm 0.02^{\mathrm{d}}$ & $6.30 \pm 0.03^{\mathrm{f}}$ & $9.60 \pm 0.05^{\mathrm{c}}$ & $4.40 \pm 0.06^{\mathrm{g}}$ & $0.61 \pm 0.05^{\mathrm{b}}$ & $1.22 \pm 0.01^{\mathrm{g}}$ \\
\hline $\mathrm{W}_{1}$ & $26.90 \pm 0.02^{\mathrm{a}}$ & $27.00 \pm 0.01^{\mathrm{a}}$ & $5.80 \pm 0.03^{\mathrm{b}}$ & $6.30 \pm 0.01^{\mathrm{f}}$ & $10.00 \pm 0.06^{\mathrm{d}}$ & $4.00 \pm 0.04^{\mathrm{h}}$ & $0.74 \pm 0.01^{\mathrm{d}}$ & $1.10 \pm 0.03^{\mathrm{f}}$ \\
\hline $\mathrm{W}_{2}$ & $26.70 \pm 0.01^{\mathrm{b}}$ & $27.10 \pm 0.03^{\mathrm{a}}$ & $5.90 \pm 0.01^{\mathrm{c}}$ & $6.20 \pm 0.02^{\mathrm{e}}$ & $10.40 \pm 0.04^{\mathrm{e}}$ & $4.00 \pm 0.05^{\mathrm{h}}$ & $0.74 \pm 0.03^{\mathrm{d}}$ & $1.22 \pm 0.05^{\mathrm{g}}$ \\
\hline $\mathrm{S}_{1}$ & $26.80 \pm 0.03^{\mathrm{b}}$ & $27.10 \pm 0.02^{\mathrm{a}}$ & $5.90 \pm 0.02^{\mathrm{c}}$ & $6.10 \pm 0.03^{\mathrm{f}}$ & $10.00 \pm 0.05^{\mathrm{d}}$ & $4.40 \pm 0.06^{\mathrm{g}}$ & $0.74 \pm 0.05^{\mathrm{d}}$ & $1.10 \pm 0.01^{\mathrm{f}}$ \\
\hline
\end{tabular}

Values are mean \pm standard deviation of triplicate determinations.

Values in the same column having the same superscript letters are not significantly different at the $5 \%$ level $(\mathrm{p} \leq$ 0.05 ).

N/B: $A=0-25 \mathrm{~cm}$ soil depth, $B=26-50 \mathrm{~cm}$ soil depth.

N, C, E, W and S are North, Central, East and Southwards from discharge points.

Subscript 1 and 2 are $10 \mathrm{~m}$ and $20 \mathrm{~m}$ respectively away from the discharge points

The results of the soil physicochemical parameters obtained in this study are as presented in table 1. The temperature $\left({ }^{\circ} \mathrm{c}\right)$ obtained in this study for both control (unpolluted soil) and test samples (polluted) ranged from $\left(26.60-27.20^{\circ} \mathrm{c}\right)$ and were not significantly different from each other $(\mathrm{P} \geq 0.05)$ when test soil samples were compared to control (table 1). The soil cation exchange capacities and exchangeable acidities significantly decreased $(p \leq 0.05)$ in the test soil samples compared to control. The temperatures obtained in the polluted soil samples showed no significant differences with respect to the unpolluted (control) samples. Baros and Morita [9] reported similar temperature ranges $\left(26.60-27.20^{\circ} \mathrm{c}\right)$ as good for most soil enzymes. However the soil $\mathrm{pH}$ of the polluted soil samples were moderately acidic. This is similar to observations of other researchers [4]. Acidic soils experience aluminum $(\mathrm{Al})$, hydrogen $(\mathrm{H})$ and or manganese $(\mathrm{Mm})$ toxicity as well as potential nutrient deficiencies of calcium $(\mathrm{Ca})$ and magnesium $(\mathrm{Mg})$ [10]. Spark[11] reported that aluminum which is not a plant nutrient is not actively taken up by plants but enters plant root passively through osmosis and damages plant root. Aluminum also binds phosphate and interferes with production of ATP and DNA. The soil cation exchange capacity (CEC) of the polluted samples were significantly $(\mathrm{p} \leq 0.05)$ low. Brandy and Weil [12] reported that high value of CEC correlates with soils of high PH.

Menge [13] reported that CEC is used as a measure of fertility, nutrient retention capacity and the capacity to protect ground water from cation contamination. Many soils CEC are dependent on the $\mathrm{pH}$ of the soil. This is mostly due to lyotrophic series which describes the relative strength of various cations absorption [14]. Thus, the dumping of this waste petroleum product led to low CEC value which indicated a decrease in the soil fertility. Also the jumping of the waste petroleum products led to decreased exchangeable acidity which 
depends on the presence of colloids in the soil. Soil $\mathrm{pH}$ values do not measure any ions that stick to colloids but only hydrogen ions that actually dissolved in a solution. The soil colloids are the most active portion of the soil and largely determine the physical and chemical properties of the soil.The dumping of this waste petroleum products probably affected the chemical and physical properties of the soil as a result the above observations. The dumping of waste petroleum products affected the availability of free phosphate ions in the soil. Eugine et al., [4] reported similar findings on polluted soil with crude oil. Nwosu [15] observed phosphate ion availability as $\mathrm{pH}$ dependent and noted that acidic soils have low phosphate since aluminum binds with phosphate and interferes with the production of ATP and DNA. This affects plant growth.

TABLE 11: SOIL SAMPLES ANION CONCENTRATION(Mdm $\left.{ }^{-3}\right)$

\begin{tabular}{|c|c|c|c|c|c|c|c|c|}
\hline \multirow{2}{*}{$\begin{array}{c}\text { Parameter } \\
\text { Depth }(\mathrm{cm})\end{array}$} & \multicolumn{2}{|c|}{ Phoshate } & \multicolumn{2}{|c|}{ Sulphate } & \multicolumn{2}{|c|}{ Chloride } & \multicolumn{2}{|c|}{ Nitrate } \\
\hline & A & B & $\mathrm{A}$ & $\mathrm{B}$ & $\mathrm{A}$ & $\mathrm{B}$ & $\mathrm{A}$ & $\mathrm{B}$ \\
\hline $\begin{array}{c}\text { Location of } \\
\text { sample } \\
\text { collected }\end{array}$ & & & & & & & & \\
\hline $\mathrm{N}_{1}$ & $55.00 \pm 0.15^{b}$ & $50.47 \pm 0.13^{f}$ & $13.73 \pm 0.07^{b}$ & $8.80 \pm 0.05^{\mathrm{c}}$ & $1.78 \pm 0.01^{b}$ & $1.07 \pm 0.02^{\mathrm{a}}$ & $25.20 \pm 0.01^{\mathrm{b}}$ & $8.40 \pm 0.01^{\mathrm{g}}$ \\
\hline $\mathrm{N}_{2}$ & $54.13 \pm 0.13^{b}$ & $50.39 \pm 0.18^{\mathrm{f}}$ & $9.39 \pm 0.05^{\mathrm{c}}$ & $8.13 \pm 0.09^{c}$ & $1.07 \pm 0.02^{\mathrm{a}}$ & $1.07 \pm 0.03+$ & $25.20 \pm 0.01^{\mathrm{b}}$ & $8.40 \pm 0.01^{\mathrm{g}}$ \\
\hline $\mathrm{C}$ & $57.88 \pm 0.18^{\mathrm{c}}$ & $51.85 \pm 0.15^{\mathrm{f}}$ & $14.51 \pm 0.09^{\mathrm{b}}$ & $13.73 \pm 0.07^{\mathrm{b}}$ & $2.49 \pm 0 . .^{03 \mathrm{c}}$ & $1.42 \pm 0.03^{\mathrm{e}}$ & $28.80 \pm 0.03^{\mathrm{c}}$ & $11.20 \pm 0.05^{\mathrm{h}}$ \\
\hline $\mathrm{E}_{1}$ & $53.19 \pm 0.15^{\mathrm{d}}$ & $50.24 \pm 0.13^{\mathrm{f}}$ & $14.09 \pm 0.07^{\mathrm{b}}$ & $8.93 \pm 0.05^{\mathrm{c}}$ & $2.13 \pm 0.01^{\mathrm{d}}$ & $1.07 \pm 0.02^{\mathrm{a}}$ & $25.20 \pm 0.02^{\mathrm{b}}$ & $7.00 \pm 0.01^{\mathrm{k}}$ \\
\hline $\mathrm{E}_{2}$ & $52.99 \pm 0.13^{\mathrm{d}}$ & $50.00 \pm 0.18^{\mathrm{g}}$ & $8.23 \pm 0.05^{\mathrm{c}}$ & $6.55 \pm 0.09^{\mathrm{d}}$ & $1.42 \pm 0.02^{\mathrm{e}}$ & $1.07 \pm 0.01^{\mathrm{a}}$ & $25.20 \pm 0.05^{\mathrm{b}}$ & $7.00 \pm 0.01^{\mathrm{k}}$ \\
\hline $\mathrm{W}_{1}$ & $47.64 \pm 0.18^{\mathrm{e}}$ & $46.26 \pm 0.15^{\mathrm{g}}$ & $13.86 \pm 0.09^{\mathrm{b}}$ & $8.13+0.07^{\mathrm{c}}$ & $1.78 \pm 0.03^{\mathrm{b}}$ & $1.07 \pm 0.01^{\mathrm{a}}$ & $22.40 \pm 0.05^{\mathrm{d}}$ & $5.60 \pm 0.02^{\mathrm{k}}$ \\
\hline $\mathrm{W}_{2}$ & $48.30 \pm 0.15^{\mathrm{e}}$ & $45.08 \pm 0.13^{\mathrm{g}}$ & $9.37 \pm 0.07^{\mathrm{c}}$ & $5.85 \pm 0.05^{\mathrm{a}}$ & $1.42 \pm 0.01^{\mathrm{e}}$ & $1.07 \pm 0.01^{\mathrm{a}}$ & $22.40 \pm 0.03^{\mathrm{d}}$ & $5.60 \pm 0.02^{\mathrm{k}}$ \\
\hline $\mathrm{S}_{1}$ & $48.03 \pm 0.13^{\mathrm{e}}$ & $46.45 \pm 0.18^{\mathrm{g}}$ & $13.97 \pm 0.05^{\mathrm{b}}$ & $9.02 \pm 0.09^{\mathrm{c}}$ & $2.13 \pm 0.02^{\mathrm{d}}$ & $1.07 \pm 0.01^{\mathrm{a}}$ & $22.40 \pm 0.03^{\mathrm{d}}$ & $5.60 \pm 0.02^{\mathrm{k}}$ \\
\hline $\mathrm{S}_{2}$ & $49.06 \pm 0.18^{\mathrm{e}}$ & $46.45 \pm 0.15^{\mathrm{g}}$ & $7.26 \pm 0.09^{\mathrm{d}}$ & $6.10 \pm 0.05^{\mathrm{d}}$ & $1.42 \pm 0.03^{\mathrm{e}}$ & $1.07 \pm 0.01^{\mathrm{a}}$ & $22.40 \pm 0.01^{\mathrm{d}}$ & $5.60 \pm 0.02^{\mathrm{k}}$ \\
\hline Control & $61.81 \pm 0.18^{\mathrm{a}}$ & $53.94 \pm 0.15^{\mathrm{d}}$ & $5.75 \pm 0.09^{\mathrm{a}}$ & $2.34+0.07^{\mathrm{e}}$ & $1.07 \pm 0.03^{\mathrm{a}}$ & $0.71 \pm 0.01^{\mathrm{f}}$ & $19.60+0.02^{\mathrm{a}}$ & $2.80+0.05^{\mathrm{f}}$ \\
\hline
\end{tabular}

Values are mean \pm standard deviation of triplicate determinations.

Values in the same column having the same superscript letters are not significantly different at the $5 \%$ level $(\mathrm{p} \leq$ $0.05)$.

N/B: $A=0-25 \mathrm{~cm}$ soil depth, $B=26-50 \mathrm{~cm}$ soil depth.

N, C, E, W and S are North, Central, East and Southwards from discharge points.

Superscript 1 and 2 are $10 \mathrm{~m}$ and $20 \mathrm{~m}$ away respectively from the discharge points.

Subscript 1 and 2 are $10 \mathrm{~m}$ and $20 \mathrm{~m}$ respectively away from the discharge points

The soil samples anion concentrations are as presented in table (II). All the anions tested significantly differed $(p \leq 0.05)$ from their controls at the various sampling depths. High values were obtained for sulphate, chloride and nitrate ions as a result of the dumping of petroleum waste products. The result obtained from this work is consistent with that made by other researchers[15]. Nwosu, [15] also reported that acid sulphate soil contain iron pyrites which react with oxygen to produce sulphuric acid in the soil. The sulphuric acid then reacts with other minerals within the soil (thus reducing their availability to plants) to release aluminum. Cisse [16] also observed that excess nitrate in soil affects soil texture which limits the water permeability or percolation rate of soil. This percolation problem will thus keep the soil devoid of water thereby affecting soil plant nutrient distribution and fertility

TABLE III: SOIL SAMPLE CATION CONCENTRATIONS (mgKg $\left.{ }^{-1}\right)$

\begin{tabular}{|c|l|l|l|l|l|l|}
\hline Parameters & Sodium & Potassium & Calcium & Magnesium & Copper & Iron \\
\hline $\begin{array}{l}\text { Locations of sample } \\
\text { collections }\end{array}$ & & & & & \\
\hline $\mathrm{N}_{1}$ & $24.23 \pm 0.35^{\mathrm{d}}$ & $42.28 \pm 0.13^{\mathrm{g}}$ & $0.59 \pm 0.8^{\mathrm{a}}$ & $0.87 \pm 0.21^{\mathrm{b}}$ & $0.09 \pm 0.31^{\mathrm{a}}$ & $0.21 \pm 0.07^{\mathrm{k}}$ \\
$\mathrm{N}_{2}$ & $31.83 \pm 0.48^{\mathrm{c}}$ & $45.60 \pm 0.10^{\mathrm{c}}$ & $0.55 \pm 0.23^{\mathrm{a}}$ & $0.77 \pm 0.18^{\mathrm{c}}$ & $0.07 \pm 0.19^{\mathrm{a}}$ & $0.20 \pm 0.18^{\mathrm{k}}$ \\
$\mathrm{C}$ & $25.65 \pm 0.20^{\mathrm{e}}$ & $38.48 \pm 0.14^{\mathrm{e}}$ & $0.57 \pm 0.30^{\mathrm{a}}$ & $0.76 \pm 0.50^{\mathrm{c}}$ & $0.11 \pm 0.25^{\mathrm{c}}$ & $0.24 \pm 0.22^{\mathrm{d}}$ \\
$\mathrm{E}_{1}$ & $26.13 \pm 0.32^{\mathrm{f}}$ & $39.43 \pm 0.11^{\mathrm{f}}$ & $0.55 \pm 0.09^{\mathrm{a}}$ & $0.80 \pm 0.23^{\mathrm{b}}$ & $0.09 \pm 0.31^{\mathrm{a}}$ & $0.22 \pm 0.26^{\mathrm{g}}$ \\
$\mathrm{E}_{2}$ & $28.98 \pm 0.23^{\mathrm{g}}$ & $43.70 \pm 0.28^{\mathrm{a}}$ & $0.53 \pm 0.19^{\mathrm{a}}$ & $0.86 \pm 0.11^{\mathrm{b}}$ & $0.08 \pm 0.25^{\mathrm{a}}$ & $0.20 \pm 0.11^{\mathrm{k}}$ \\
$\mathrm{W}_{1}$ & $28.03 \pm 0.26^{\mathrm{k}}$ & $43.23 \pm 0.13^{\mathrm{a}}$ & $0.59 \pm 0.13^{\mathrm{a}}$ & $0.86 \pm 0.12^{\mathrm{b}}$ & $0.11 \pm 0.25^{\mathrm{c}}$ & $0.24 \pm 0.13^{\mathrm{d}}$ \\
$\mathrm{W}_{2}$ & $30.88 \pm 0.14^{\mathrm{j}}$ & $46.55 \pm 0.006^{\mathrm{b}}$ & $0.58 \pm 0.12^{\mathrm{a}}$ & $0.78 \pm 0.14^{\mathrm{c}}$ & $0.10 \pm 0.00^{\mathrm{c}}$ & $0.22 \pm 0.00^{\mathrm{g}}$ \\
$\mathrm{S}_{1}$ & $29.93 \pm 0.17^{\mathrm{l}}$ & $44.65 \pm 0.17^{\mathrm{h}}$ & $0.54 \pm 0.18^{\mathrm{a}}$ & $0.78 \pm 0.11^{\mathrm{c}}$ & $0.10 \pm 0.00^{\mathrm{c}}$ & $0.23 \pm 0.13^{\mathrm{d}}$ \\
$\mathrm{S}_{2}$ & $27.55 \pm 0.18^{\mathrm{a}}$ & $40.85 \pm 0.32^{\mathrm{g}}$ & $0.52 \pm 0.21^{\mathrm{a}}$ & $0.80 \pm 0.12^{\mathrm{b}}$ & $0.07 \pm 0.19^{\mathrm{a}}$ & $0.07 \pm 0.00^{\mathrm{a}}$ \\
$\mathrm{Control}$ & $22.80 \pm 0.40^{\mathrm{h}}$ & $36.58 \pm 0.11^{\mathrm{k}}$ & $0.52 \pm 0.34^{\mathrm{a}}$ & $0.83 \pm 0.22^{\mathrm{b}}$ & $0.05 \pm 0.13^{\mathrm{b}}$ & $0.18 \pm 0.11^{\mathrm{a}}$
\end{tabular}


Values are mean \pm standard deviation of triplicate determinations.

Values in the same column having the same superscript letters are not significantly different at the $5 \%(\mathrm{p} \leq 0.05)$ N/B: Soil depth $=0-50 \mathrm{~cm}$

N,C,E,W and S are North, Central, East, West and Southwards from the discharge point.

Subscripts 1 and 2 are $10 \mathrm{~m}$ and $20 \mathrm{~m}$ respectively away from discharge point.

In the table (111), the results obtained for the soil sample cations are presented. Sodium, potassium, copper and iron were significantly higher $(\mathrm{p} \leq 0.05)$ in test soils compared to control samples while magnesium ion was lower $(p \leq 0.05)$ in the test soil. However soil calcium ion did not change significantly $(p \geq 0.05)$. High values of sodium and potassium in this work was associated with mineralization in the soil during the formation of sulphuric acid[15]. This high sodium and potassium (as described here) are not made available to plants as they bind to other structures like colloids. The low concentrations of calcium and magnesium as a result of the waste dumping may be due to poor soil structure (Colloids) which probably leads to poor fertility of the soil. Low CEC and acidic soils also account for low levels of soil $\mathrm{Ca}^{2+}$ and $\mathrm{Mg}^{2+}$ ion [4]. Similarly high values of copper and iron obtained in this work is in agreement with that off previous researchers [4,17].High concentration of copper and iron in soils lead to toxicity problems[18].

TABLE 1V: SOIL SAMPLE ENZYMES ACTIVITIES

\begin{tabular}{|c|c|c|c|c|c|c|c|c|}
\hline \multirow{2}{*}{$\begin{array}{c}\text { Parameter } \\
\text { Soil Depth } \\
\end{array}$} & \multicolumn{2}{|c|}{ pehydrogenase (mgTPFg ${ }^{-1}$} & \multicolumn{2}{|c|}{ Ikaline Phosphate (Iug $^{-1}$} & \multicolumn{2}{|c|}{ Acid Phosphase $\left(\mathrm{Iug}^{-1}\right)$} & \multicolumn{2}{|c|}{ Lipase (Iug $\left.{ }^{-1}\right)$} \\
\hline & $\mathrm{A}$ & $\mathrm{B}$ & $\mathrm{A}$ & $\mathrm{B}$ & $\mathrm{A}$ & $\mathrm{B}$ & A & $\mathrm{B}$ \\
\hline \multicolumn{9}{|l|}{$\begin{array}{l}\text { Location of sample } \\
\text { collection }\end{array}$} \\
\hline $\mathrm{N}_{1}$ & $\begin{array}{l}1.3 \times 10^{-} \\
{ }^{6} \pm 0.01^{\mathrm{b}}\end{array}$ & $.0 \times 10^{-6} \pm 0.03^{h}$ & $0.45 \pm 0.03^{b}$ & $0.46 \pm 0.05^{b}$ & $2.56 \pm 0.03^{b}$ & $7.68 \pm 0.02^{g}$ & $3.20 \pm 0.03^{b}$ & $3.20 \pm 0.03^{\mathrm{b}}$ \\
\hline $\mathrm{N}_{2}$ & $\begin{array}{l}7.1 \times 10^{-} \\
{ }^{6}+0.03^{\mathrm{c}}\end{array}$ & $.0 \times 10^{-6} \pm 0.02^{\mathrm{e}}$ & $0.33 \pm 0.01+$ & $0.92 \pm 0.01^{\mathrm{h}}$ & $2.56 \pm 0.01^{\mathrm{b}}$ & $6.82 \pm 0.01^{\mathrm{h}}$ & $3.00 \pm 0.03^{\mathrm{b}}$ & $2.60 \pm 0.02^{\mathrm{a}}$ \\
\hline $\mathrm{C}$ & $\begin{array}{l}1.2 \times 10^{-} \\
{ }^{7}+0.02^{j}\end{array}$ & $.6 \times 10^{-7} \pm 0.01^{\mathrm{j}}$ & $0.14 \pm 0.02^{\mathrm{d}}$ & $0.22 \pm 0.04^{\mathrm{e}}$ & $1.71 \pm 0.01^{\mathrm{c}}$ & $5.12 \pm 0.03^{\mathrm{j}}$ & $4.80 \pm 0.04^{\mathrm{e}}$ & $4.80 \pm 0.04^{\mathrm{e}}$ \\
\hline $\mathrm{E}_{1}$ & $\begin{array}{l}1.1 \times 10^{-} \\
{ }^{7}+0.01^{\mathrm{b}}\end{array}$ & $\therefore .0 \times 10^{-6} \pm 0.03^{\mathrm{k}}$ & $0.49 \pm 0.04+$ & $0.67 \pm 0.03^{j}$ & $2.56 \pm 0.02^{\mathrm{b}}$ & $5.12 \pm 0.03^{j}$ & $3.40 \pm 0.03^{\mathrm{d}}$ & $3.20 \pm 0.03^{\mathrm{b}}$ \\
\hline $\mathrm{E}_{2}$ & $\begin{array}{l}1.3 \times 10^{-} \\
{ }^{6}+0.03^{\mathrm{b}}\end{array}$ & $2.6 \times 10^{-6 \pm} 0.02^{1}$ & $0.51 \pm 0.04^{\mathrm{b}}$ & $0.48 \pm 0.05^{b}$ & $3.41 \pm 0.03^{\mathrm{d}}$ & $6.82 \pm 0.01^{\mathrm{h}}$ & $2.80 \pm 0.02^{\mathrm{e}}$ & $3.20 \pm 0.03^{\mathrm{b}}$ \\
\hline $\mathrm{W}_{1}$ & $\begin{array}{l}1.4 \times 10^{-} \\
{ }^{6} \pm 0.02^{\mathrm{d}}\end{array}$ & $.0 \times 10^{-6} \pm 0.03^{\mathrm{m}}$ & $0.47 \pm 0.03^{\mathrm{b}}$ & $0.73 \pm 0.03^{j}$ & $2.56 \pm 0.02^{\mathrm{b}}$ & $7.68 \pm 0.01^{\mathrm{g}}$ & $3.20 \pm 0.03^{\mathrm{b}}$ & $3.00 \pm 0.03^{\mathrm{b}}$ \\
\hline $\mathrm{W}_{2}$ & $\begin{array}{l}1.8 \times 10- \\
6+0.01^{\mathrm{n}}\end{array}$ & $\begin{array}{c}.4 \times 10^{-6} \pm 0.02^{\mathrm{d}} \\
\pm\end{array}$ & $0.37 \pm 0.01^{\mathrm{c}}$ & $1.00 \pm 0.01^{\mathrm{h}}$ & $2.56 \pm 0.03^{\mathrm{b}}$ & $6.82 \pm 0.01^{\mathrm{h}}$ & $2.80 \pm 0.03^{\mathrm{e}}$ & $2.80 \pm 0.02^{\mathrm{e}}$ \\
\hline $\mathrm{S}_{1}$ & $\begin{array}{l}1.0 \times 10^{-} \\
{ }^{-}+0.03^{\mathrm{e}}\end{array}$ & $.0 \times 10^{-6} \pm 0.01^{\mathrm{m}}$ & $0.24 \pm 0.05^{\mathrm{e}}$ & $0.81 \pm 0 . .^{02 \mathrm{k}}$ & $3.41 \pm 0.01^{\mathrm{d}}$ & $7.68 \pm 0.01^{\mathrm{g}}$ & $3.80 \pm 0.03^{\mathrm{f}}$ & $2.80 \pm 0.02^{\mathrm{e}}$ \\
\hline $\mathrm{S}_{2}$ & $\begin{array}{l}3.7 \times 10^{-} \\
{ }^{6} \pm 0.02^{\mathrm{f}}\end{array}$ & $\begin{array}{c}8.0 \times 10^{-6} \pm \\
0.01^{\mathrm{m}}\end{array}$ & $0.56 \pm 0.02^{\mathrm{f}}$ & $0.15 \pm 0 . .^{04 d}$ & $4.27 \pm 0.02^{\mathrm{e}}$ & $11.94 \pm 0.03^{\mathrm{f}}$ & $3.00 \pm 0.03^{\mathrm{b}}$ & $2.60 \pm 0.02^{\mathrm{a}}$ \\
\hline Control & $\begin{array}{l}1.8 \times 10^{-} \\
{ }^{5} \pm 0.02^{\mathrm{a}}\end{array}$ & $.4 \times 10^{-5} \pm 0.01^{\mathrm{g}}$ & $2.85 \pm 0.05^{\mathrm{a}}$ & $1.80 \pm 0.02^{\mathrm{g}}$ & $6.82 \pm 0.02^{\mathrm{a}}$ & $6.84 \pm 0.04^{\mathrm{g}}$ & $2.40 \pm 0.02^{\mathrm{a}}$ & $2.40 \pm 0.02^{\mathrm{a}}$ \\
\hline
\end{tabular}

Values are mean \pm standard deviation of triplicate determinations.

Values in the same column having the same superscript letters are not significantly different at the $5 \%$ level $(\mathrm{p} \leq$ $0.05)$.

N/B: $A=0-25 \mathrm{~cm}$ soil depth, $B=26-50 \mathrm{~cm}$ soil depth.

N, C, E, W and S are North, Central, East and Southwards from discharge points.

Subscript 1 and 2 are $10 \mathrm{~m}$ and $20 \mathrm{~m}$ respectively away from the discharge point

Soil enzymes activities are as presented in table (1V). The results obtained indicated that the soil dehydrogenase activity decreased significantly $(\mathrm{p} \leq 0.05)$ compared to control. Similarly while the acid phosphatase activity was lower $(\mathrm{p} \leq 0.05)$ in the test samples, alkaline phosphatase activity was also low $(\mathrm{p} \leq 0.05)$. In both cases, the discharge point of the waste petroleum product was most affected. The soil lipase enzyme also significantly $(\mathrm{p} \leq$ 0.05 ) increased in test soil sample compared to control. Low enzymes activities were observed for dehydrogenase, acid phosphatase and alkaline phosphatase while lipase activity was high. The result obtained from this work is consistent with that made by previous researchers on enzymes in polluted or contaminated soil[17,19,20]. Dehydrogenase activity serves as an indicator of the microbiological oxidative activities in soil [21]. Also dehydrogenase occurs intracellularly in living cells unlike other enzymes which can occurs in extra cellular state. Thus low dehydrogenate activities as a result of this dumping of petroleum waste product indicates low microbial cell multiplication as a result of low availability of nutrients. Tabatabai [22] reported that a decrease in phosphatase activities in soil reduces nutrient mineralization to plant. This means that the 
fertility of the soil is mostly affected. However, the high lipase activities obtained in this work is as a result of nutrient availability. Pogari et al., [23] reported that certain enzymes that are produced by some microorganisms especially bacteria and fungi help to degrade most pollutants especially those of hydrocarbon origin. Thus, an increase in lipase activity as a result of this waste dumping is indicative of the soils ability to undergo bioremediation thereby making itself more productive agriculturally.

\section{Conclusion}

This study has shown that the dumping of waste petroleum products affected the levels of some soil inorganic cations and anions. The concentration of some ions analyzed were on the high side, indicating their high pollution potential, especially if no treatment measures are taken. The ecology of the soil was probably disrupted leading to decreased soil enzyme activities going on in the soil. This affects plant soil nutrient availability and will deplete crop yield. It is therefore postulated that a proper remediation methods be applied to the polluted area to enhance agricultural productivity.

\section{Reference}

[1] A.G.Ryder ,P. Iwanski and L. Montanari L. Fluorescence emission from petroleum; a valuable information source for petroleum analysis in-house. Journal for Entecnologic 2: 2004,9-14

[2] H. Kobayashi, and B.E Rittman, B .Microbial removal of hazardous organic compounds; Enviorn. Sci. Technol. 19(3), 1982, 470481A.

[3] G.W. Pettibone, and J.I. Cooney, "Toxicity of methyltins to microbial populations in estuarine sediments", J. Indust, Microbiol. 2: 1988, 373-378.

[4] Z. Daniel . Fundamentals of soil exchange acidicity. Soil Bro.sci.17, 2008,79-80.

[5] N.O.Eugene,I.O. Stanley, and M.N. Nwubani. Inorganic ion levels of soils and streams in some areas of Ogoni land, Nigeria as affected by crude oil spillage; J, Appl. Sci. Environ. manage. 4, 2002,!91-203.

[6] R.G. Bates. Electronic pH Determination. 3ohn Wiley and Sons Inc. New York.1954.

[7] J.Dewis, and F. Freitas. Physical and chemical methods of soil and water analysis. Soil Bulletin 10 FAO, Rome. 1-275. 1970.

[8] A. Thalman Zur methodic dev' Bestimmung der. Dehydrogenase activities in Boden mittels triphenyltetra Zolium chloride (TTC) land Wirtsch Forsch 21, 1968, 249-258.

[9] J.A. Baross, and R.Y. Morita. Microbial life at low temperature; Ecological Aspects. In: DJ Kushner (ed) Microbial life in extreme Environments, Academic Press New York. Pp. 9-71.1978.

[10] S.W.Buol, R.S Southard, R.C. Graham and P.A. MC Daniel. Soil Genesis and classification. 5th edition, La State Press. Pp 494-502. 2002.

[11] D. Sparks. Environmental soil chemistry. Academic press London, UK pp72-79.2003.

[12] N.C. Brandy, and R. R. Weil. The nature and properties of soils (12th ed) prentice hall. Inc, New 3ersy. Pp890-897.1999.

[13] D.D.Menge. Fundamentals of soil cation exchange capacity, Trans Comm. II and IV. Int. Soc. Science pp. 208-205.2011

[14] T. Halving and N. Beaton. Soil fertility and fertilizers. New Delhi PHI pp72-78.2011

[15] C.J. Nwosu. "Effect of crude oil pollution on some mineral and nutrient content of soil and cassava plants in Rivers State Nigeria; M. Sc. Thesis, University of Port Harcourt, Nigeria (unpublished). 1994.

[16] A.A. Cisse .(2008) Nitrate: heath effect in dirking water and management for water quality. Environ, Res. 2, $2008,311-316$.

[17] V.O. Nwaugo, R.A. Onyeagba, E.I. Akubugwo, and O.Ugbogu. Soil bacteria flora and enzymatic activities in Zinc and Lead contaminated soil. BIOKEMISTRI 20(2),2008, 77-84.

[18] G. Stotzky. Soil as an environment for microbial life In modern soil microbiology. Marcel Dekker Inc. New York. pp. 1-20. 1997

[19] M.J. Rowell, and L.Z. Florence."Characteristics associated with difference between undisturbed and industrially disturbed soils". Soil Boil. Bipchem. 25, 1993, 1499-1511.

[20] I.E. Akubugwo, C..Ogbuji ,.G .C. Chinyere, and A.E.Ugbogu .Physicochemical properties and enzymes activity studies in a refined oil contaminated soil in Isuikwuato, Abia State,Nigeria. Biokemistri 21(2) 2009,79-84

[21] M.A.Tabatabai . Soil enzymes; Methods of soil analysis part 2. Microbiological and biochemical properties. Pp775-833.1994.

[22] N. Pogari, V. XU and A. Cheikhyousset . Potential aspects of lipases obtained from Rhizopus fungi. Res. J. Microbiol., 2: 2007,101116. 